\title{
eCOti
DiAno
}

Revista Mídia e Cotidiano

Artigo Seção Temática

Volume 13, Número 2, agosto de 2019

Submetido em: 17/06/2019

Aprovado em: 24/07/2019

\section{Maffesoli e Heidegger: a fenomenologia comum do ver por si mesmo}

\section{Maffesoli e Heidegger: the common phenomenology of seeing for yourself}

\author{
Eduardo Portanova BARROS ${ }^{1}$
}

\begin{abstract}
Resumo
Este artigo postula uma aproximação teórico-conceitual entre Michel Maffesoli e Martin Heidegger a partir do Método Fenomenológico. Entende-se que ambos propõem uma leitura ensaística, com diferenças de abordagem, no entanto, sobre a facticidade ontológica do humano no seu espaço-tempo "societal". Em Maffesoli, a conotação fenomenológica é um aspecto afirmativo da existência. Já em Heidegger é uma possibilidade de pensamento sobre a relação entre o Ente e o Ser. Daí a diferença na abordagem. Mas ambos, porém, partem do mesmo pressuposto, o de um fenômeno que se mostra a si mesmo.
\end{abstract}

Palavras-chave: Maffesoli; Heidegger; fenomenologia; imaginário; técnica; cotidiano.

\begin{abstract}
This article proposes establishing a theoretical-conceptual dialogue between Michel Maffesoli and Martin Heidegger, drawing from the Phenomenological Method. It is understood that they both propose an essayist reading, even though they adopt different approaches in relation to the ontological facticity of the human in society. In Maffesoli's work, the phenomenological connotation represents an affirmative aspect of existence, whilst in Heidegger's work it represents the possibility of thinking about the relationship between the Self and the Being. Both authors, however, share the same starting point, that of a phenomenon that reveals itself.
\end{abstract}

Keywords: Maffesoli; Heidegger; phenomenology; imaginary; technique; everyday life.

\footnotetext{
${ }^{1}$ Pós-doutor pela Sorbonne (Université Paris Descartes V) e pelo PPG em Ciências Sociais da Unisinos (São Leopoldo-RS), doutor em Comunicação Social pela PUCRS e mestre em Ciências da Comunicação pela ECA/USP. Tradutor de "Sociologia do imaginário" (LEGROS, P et alli. Sulina: Porto Alegre, 2014. 2a. ed.) e de "Pactos emocionais: reflexões em torno da moral, da ética e da deontologia" (MAFFESOLI, M. Curitiba: PUCPRESS, 2018). Autor de "Truffaut, o homem que amava o cinema" (Ed. da Ulbra: Canoas, 2013) e de "Maffesoli: entre a ciência alegre e o demasiado humano. Aproximações de uma Sociologia Anarquista" (São Leopoldo: Oikos, 2014). Pesquisador do Grupo de Pesquisa sobre Comunicação e Imaginário Imaginalis (UFRGS-CNPQ). E-mail: eduardoportanova@ hotmail.com
} 


\section{Introdução}

Não foram poucas as vezes que o sociológo francês Michel Maffesoli (Graissessac-sur-Mer, 1944) se referiu em sua obra, já bastante extensa no Brasil, a Martin Heidegger (1889-1976), o filósofo alemão da Analítica da Presença, isto é, do Ente que somos. Deixemos claro, para acompanhar o raciocínio de Heidegger, desde já, que o Ente, para ele, não é o Ser. Para Heidegger, o "ser é indefinível” (2015, p. 39). Porém, ele mesmo acrescenta, "a indefinibilidade do Ser não dispensa a questão do seu sentido, ao contrário, justamente por isso a exige" (HEIDEGGER, 2015, p. 39). Pois essa dialética entre Ser-Ente, que, em Maffesoli, poderíamos denominar "razão sensível” é o que os aproxima. E aqui, nesse artigo, é disso que se trata: procurar algumas aproximações entre eles, dado que Heidegger é o filósofo que, depois de Nietzsche (1844-1900), talvez tenha sido a maior influência no pensamento libertário maffesoliano.

Heidegger deixa como um dos seus legados de cunho filosófico sua reflexão sobre a questão - como "ethos" - da técnica. Maffesoli também investiga uma ética, por seu lado, inspirado que foi, primeiramente, por Nietzsche, de uma sociedade que vive. Mesmo que Heidegger não tenha um posicionamento autocrítico libertário, isto é, não exista nele - e nunca exitiu, até onde sabemos - preocupação alguma em defender um estilo de pensamento, ele, Heidegger, apresenta um viés semelhante ao de Maffesoli (e vice-versa) no sentido de se interessar por posições contra-hegêmonicas (genericamente falando). Se filosoficamente a metafísica sempre buscou a resposta para o Ser, Heidegger, pelo contrário, irá procurá-la numa fenomenologia. "Fenomenologia diz: deixar e fazer ver por si mesmo aquilo que se mostra, tal como se mostra a partir de si mesmo" (HEIDEGGER, 2015, p. 74).

\section{O mundo metafísico}

O imaginário, da forma como pensa não só Heidegger como Maffesoli, é, possivelmente, o entre-dois da natureza humana, e não só um aparato tecnológico acabado ou um problema de método, respectivamente. Para Maffesoli, o "carpe diem". Para Heidegger, a questão do Ser. A “questão" da técnica (como dispêndio de Si) é uma das características do Ser, segundo Heidegger. Ser este que não está isolado no mundo 


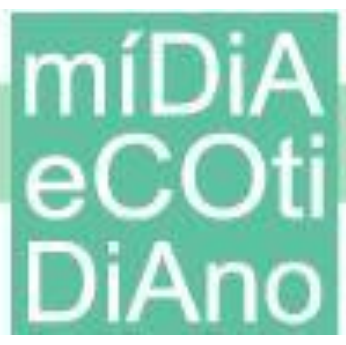

metafísico, pois há sempre com este Ser um Ente. Essa relação dialética é também a forma como pensa Maffesoli, mas antes pelo viés em Nietzsche (2002) das tragédias gregas e dos seus respectivos instintos apolíneo e dionisíaco. O Ser e o Ente caminham juntos, assim como a tecnologia é uma extensão do homem (tanto quanto o homem fomenta esse componente tecnológico em sua existência). Maffesoli não faz um trabalho extenso sobre o Homem, ao contrário de Heidegger. Mas se serve de Heidegger para falar do Homem no seu cotidiano. Ou do cotidiano para falar do Homem.

O que Maffesoli apresenta, de maneira ensaística, é um questionamento sobre o imaginário humano e as relações entre os indivíduos, preferencialmente a partir de seu lugar, fazendo convergir duas abordagens pelo menos, a sociológica e a filosófica. Já Heidegger faz uma filosofia da questão que envolve a técnica, sem usar a terminologia de imagem ou imaginário, e que não é, tampouco, a mesma da linha de estudos adotada por Ernst Kapp (1808-1896) em seus "Fundamentos [ou Princípios] de uma filosofia da técnica”, em 1887. Linha essa que trata da técnica como extensão dos órgãos humanos, numa espécie de filosofia biotécnica dos corpos vivos. Mas não é assim para Heidegger ou Maffesoli. Pergunta Heidegger: "Qual é o papel da técnica e o que está em jogo por meio da técnica?". Resposta: a questão do Ser.

\section{A Filosofia da Diferença}

Maffesoli, influenciado por Nietzsche, responderia: "É o trágico". Heidegger, ao contrário de Maffesoli, tem um projeto, que começa nos primeiros anos do século 20, que é o de desconstruir o pensamento ocidental, distanciando-se de seus pressupostos heurísticos para melhor observá-los à distância. A Filosofia da Diferença, de Heidegger, também foi uma influência no trabalho de Maffesoli, mas não como o fora Nietzsche. Maffesoli se debruça em Heidegger depois de ler Nietzsche, e o mantém vivo ainda hoje, mesmo buscando em Heidegger, agora, grande parte de suas reflexões. Não seria nenhum despropósito considerar Maffesoli um pós-estruturalista, uma corrente influenciada pela Filosofia da Diferença, de Heidegger. Até porque Maffesoli admira e, por vezes, prolonga Foucault. Com Nietzsche e Heidegger, portanto, se dá uma nova forma de pensar, essa mesma, a de uma Filosofia da Diferença. Para Maffesoli, é um modo libertário de pensamento. 


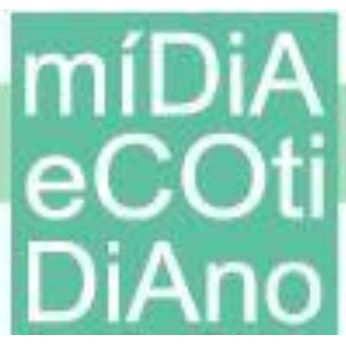

Essa Filosofia da Diferença se ancora num pensamento que já não é mais o da modernidade enquanto projeto, progresso ou força. Por isso, mais tarde, dentro de seus estudos filosóficos na Universidade de Turim, e próximo a Maffesoli, Gianni Vattimo, discípulo de Luigi Pareyson, chamará essa Filosofia da Diferença heideggeriana, que também pode ser denominada Filosofia da Suspeita (sobretudo a partir de Nietzsche), de Pensamento Débil. Maffesoli, Heidegger e, agora, Vattimo (1996) têm em comum sua admiração pelas ideias de Nietzsche. Todos os três são herdeiros da Filosofia da Suspeita do autor de "Além do bem e do mal". Maffesoli e Vattimo tratam deste tempo presente como um tempo da pós-modernidade. "Considero o trabalho de Vattimo esclarecedor para entender a agonia dos tempos modernos", afirma Maffesoli (2018, p. 66). Vejamos, passando para outra etapa, a presença desse questionamento de Heidegger sobre a questão da técnica no escopo teórico maffesoliano.

\section{A “questão da técnica"}

Para Heidegger, promovendo a desconstrução do pensamento ocidental por um viés crítico, não se trata de abordar a técnica em si, mas a "questão" subjacente a essa técnica e que ele irá chamar de "questão da técnica". Qual é, pergunta Heidegger, o problema ou a questão que está em jogo por meio da técnica? E de que forma o homem se relaciona com essa técnica? Heidegger questiona o que está dentro da técnica, mas não uma filosofia da técnica (apesar de, em se tratando do que está dentro da técnica, acabar, sim, fazendo uma filosofia da técnica). Esse, porém, não é o ponto. Heidegger, portanto, é antes um filósofo da "questão da técnica". Nietzsche disse que o homem não é senhor do seu pensamento, e é essa a "questão da técnica" heideggeriana. Pode a técnica pensar pelo homem? Maffesoli, que se inspira no jeito circular da reflexão heideggeriana, considera a técnica, junto com o arcaísmo, o espírito da pós-modernidade. "Armação" é a vida ordenada da técnica, conforme Heidegger.

Maffesoli não entende "armação" da forma que Heidegger postula. Isso porque a sociedade, pelo viés maffesoliano, é estruturalmente mítica, sem uma característica única de pensamento, como a que Heidegger parece definir com "armação". Porém, a ideia de "ultrapassamento" (assim como Martin Heidegger se referiu à metafísica) de uma sociedade moderna a uma pós-modernidade, sim, faz sentido tanto 


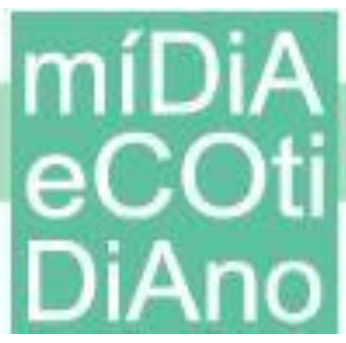

para Maffesoli quanto para Heidegger. Não se trata de utilização da lente do positivismo mas, a de contornos cristalinos para a chamada "nebulosa social" (Maffesoli). Enquanto Maffesoli estuda o comportamento de grupos (como no caso dos coletes amarelos, por exemplo), ou seja, a Sociologia em que a sociedade se vê (esse é um caráter fenomenológico oriundo de Heidegger), já o filósofo alemão discute o pensar de uma sociedade.

O trágico se instala, por exemplo, aquele trágico que pode ser mostrado (isso é bem heideggeriano), e não demonstrado. Outro ponto em comum entre Maffesoli e Heidegger, mas que temos de matizar, é o relativismo. Maffesoli é tão relativista quanto Heidegger ao considerar a alternância de paradigmas. Não se aceita mais o controle, mas o orgiasmo (mistura de sentimentos), o contato, o efêmero. Mais vale o discurso panfletário (por redes sociais, preferencialmente) de um político do que o seu conteúdo. O que Heidegger diz é que o Ser se projeta para além da identidade. Maffesoli, por sua vez, trata da diferença entre identidade e o que ele irá chamar de identificação. Talvez o que Maffesoli e Heidegger tenham em comum nesse quesito identitário seja a possibilidade de não mais se procurar um traço único como marca pessoal. Para Maffesoli, é o jogo duplo, a máscara social. Para Heidegger, é o Ente.

\section{Saturação}

A saturação do mundo é algo em comum entre Maffesoli e Heidegger. Maffesoli fala de uma hoje ambiência emocional, enquanto Heidegger prefere pensar em termos de ausência reflexiva sobre o Ser. Não se trata tanto de argumento, nem para Heidegger e menos ainda para Mafffesoli, mas de um conhecimento mais amplo do que a técnica e a tecnologia. O problema é o que vem a ser essa amplitude. A amplitude, para Maffesoli, não tem um sentido profundo, mas aparente. $O$ de Heidegger, um fenomenólogo metafísico, por assim dizer, é o caso, sim, de escavar, mergulhar no pensamento crítico e vislumbrar uma tomada de consciência. Conhecimento e técnica remetem à dimensão metafísica do mundo. Mesmo considerando a metafísica como uma objetivação da existência que não tem mais respaldo, sempre somos metafísicos, querendo ou não. 


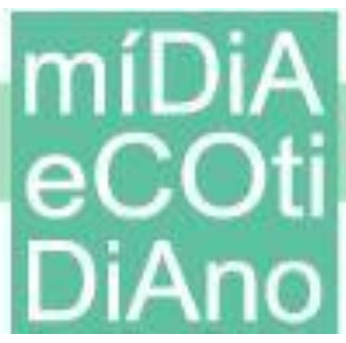

Portanto, Maffesoli é o teórico de uma fenomenologia do imaginário baseada no cotidiano sob o viés de um estar-junto societal. A vida é afirmativa, e se o uso da técnica prevalece, tanto faz. Mas não para Heidegger, isso porque, segundo ele, é preciso questionar: "Por que se inventam esses mecanismos?". Heidegger, em um dos artigos de seu livro "Ensaios e conferências", o mesmo livro no qual escreve sobre "A questão da técnica", é bem claro: "É preciso que nos disponhamos a aprender a pensar" (2008, p. 11). Não em Maffesoli. A fenomenologia cotidiana em Maffesoli é ação. Em Heidegger, é o que ele denomina "redução fenomenológica" (2012, p. 36). O objetivo é sempre o Ser, conforme Heidegger. Mas não o é a fenomenologia maffesoliana, apesar de haver ressonâncias entre a fenomenologia tanto em um quanto em outro. "O método fenomenológico não se esgota com a construção fenomenológica" afirma Heidegger (2012, p. 37). Em Maffesoli, por outro lado, parece que sim.

\section{"Por que a técnica?"}

Uma diferença importante entre Maffesoli e Heidegger é o fato de que, para Heidegger, o desejo que o pensamento ocidental tem de explicar tudo por meio não só do pensamento tecnológico como também maquínico - ou maquinístico, se preferirem - traz sérias consequências. Mais do que isso, pode até levar ao desaparecimento desse mesmo homem tecnológico. Lembremo-nos de que Heidegger pretende refletir sobre o Ente para alcançar o Ser. Mas não Maffesoli, segundo o qual a vida, se vivida afirmativamente, como na filosofia do "dizer sim" em Nietzsche, não se questiona nesses termos ontológico-metafísicos heideggerianos. Heidegger trará um termo, o de "apropriação", que relaciona o homem a um elemento misterioso. A técnica é, precisamente, esse mistério no sentido de que nos define e, portanto, dela nos "apropriamos". A armação, para Heidegger, é a construção do mundo como máquina.

Ora, Maffesoli não se pergunta: "Por que a técnica?". Para ele, ao contrário, não precisamos pensar nisso, mas compreender apenas que o interesse pelo "tudo tecnológico" é “cimento social”. Isso porque, na pós-modernidade, afirma Maffesoli, esse mesmo cotidiano marcado pela tecnologia será a expressão da vida definida pelo qualitativo. O que interessa a técnica desde que possamos dele tirar proveito? Mas Heidegger diria: "Vemos a tecnologia ou ela nos vê?". As características do chamado 


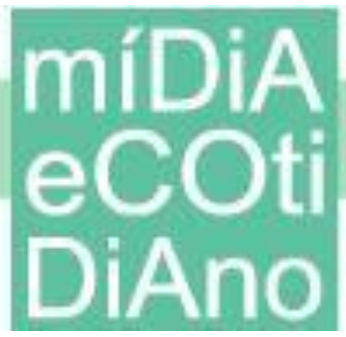

Projeto da Modernidade, que eram codificar, classificar e ordenar, de acordo com Maffesoli (2018), esfacelaram-se. Por outro lado, na chamada pós-modernidade, que é o termo mais próximo dessa efervescência orgiástica, de acordo com Maffesoli, e agora um termo mais ou menos consensual, o foco é no trágico, no conflito entre Apolo (o Deus da Razão) e Dionísio (o Deus do Vinho, que é Baco, orgia).

\section{A Sociologia Compreensiva}

Por vezes, Maffesoli se vale mais de Max Weber (1864-1920), o sociólogo alemão do "espírito do capitalismo", do que Heidegger. Na verdade, Maffesoli transita, surfa em autores de diferentes posicionamentos e escolas. Com isso, queremos evidenciar um traço forte no pensamento maffesoliano, que é, precisamente, seu cunho sociofilosófico. Sim, é difícil defini-lo por um só campo de estudo. Porém, aqui procuramos identificar nesse pluralismo metodológico a presença heideggeriana. Heidegger é o autor com que Maffesoli forma um quadrilátero conceitual de sua epistemologia. E é nesse pluralismo que se situa Heidegger. Ora, se Maffesoli não se apega a uma ou outra escola, é, justamente, esse perfil que lhe dá a oportunidade de se referir a Heidegger com alguma frequência, mesmo não sendo Heidegger presença tão constante quanto Nietzsche, Weber ou George Simmel (1858-1918).

Weber admite que "a sociologia tenta abranger também vários fenômenos irracionais, isto é, míticos, proféticos, espirituais, bem como afetivos” (2002, p. 32). Pelo viés da Sociologia Compreensiva, é possível incluirmos na análise uma forma de raciocínio similar àquilo que estamos descrevendo, e julgamos ser isso extremamente necessário para que o investigador e o "objeto" de sua investigação falem a mesma língua. Se não fosse assim, a pesquisa se transformaria apenas em uma forma vazia, porque tentaria falar de algo contrário, nos próprios termos, ao assunto estudado. E isso se vê muito. Em outras palavras: para falar de Maffesoli de modo compreensivo, precisamos ser compreensivos com o seu modo de falar. Quando Maffesoli se refere a Heidegger em "O conhecimento comum", analisa nele aquilo que Gadamer descreve como um dos maiores méritos do pensador alemão de "Ser e tempo": exibir as coisas. 


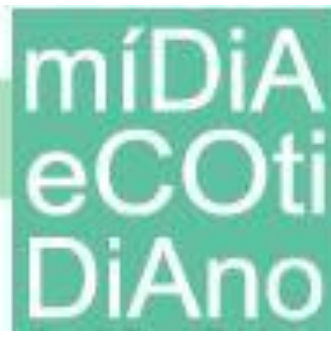

\section{A "fenomenologia complexa"}

É isso que Maffesoli admira em Heidegger, o filósofo da exibição das coisas, assim como ele, Maffesoli, acredita fazê-lo dentro de uma "fenomenologia complexa que saiba integrar a participação, a descrição, as histórias de vida e as diversas manifestações dos imaginários coletivos" (2007, p. 246). Daí é que Maffesoli subtrai a fenomenologia heideggeriana para sua análise "compreensiva". De acordo com Rüdiger, "Maffesoli vem construindo uma reflexão polêmica e questionadora, que se mostra relevante para a compreensão do interesse há pouco readquirido pelo conceito de conduta não-racional" (2002, p.14). Tanto quanto pela sua aplicação ao estudo da sociedade contemporânea, complementa ele. Para Rüdiger, Maffesoli está certo na radiografia, e não no diagnóstico. Isso porque Rüdiger esperava, conforme diz, um "conceito de razão mais esclarecido" (2002, p.142).

Podemos exemplificar o que Maffesoli chamou de uma "fenomenologia complexa", baseada em Heidegger, a partir de seus cinco pressupostos teóricos em "O conhecimento comum": (1) crítica ao dualismo esquemático, (2) a forma, (3) uma sensibilidade relativista, (4) uma pesquisa estilística e (5) um pensamento libertário. Estes cinco pontos configuram uma metodologia "aplicável” em trabalhos científicos, cujo objetivo é o de situar a pesquisa naquilo que o autor entende por "razão sensível", a ambivalência entre o dado concreto e o espírito do tempo, sem prejuízo de um em relação ao outro. Todos estes postulados formam um “corpus” de aplicação em diferentes áreas do conhecimento. Poderíamos dizer, admitindo certo reducionismo, que estes pressupostos são a "teoria aplicada" de Maffesoli. Quer dizer: o pesquisador que procurasse se valer dos estudos maffesolianos para escrever algum trabalho científico encontraria nos cinco pressupostos uma metodologia clara. Porém, cada pressuposto destes traz, em si, uma série de reflexões em cascata, digamos.

\section{Os cinco pressupostos}

Cada um deles amplia o universo de pesquisa para outras áreas do conhecimento; para além da Sociologia. Isso porque Maffesoli fala por aproximações. Ou seja, as respostas não estão dadas de modo apriorístico, em virtude do estilo ensaísticofenomenológico nos seus livros. Em relação ao pensamento crítico (1), Maffesoli oferece 


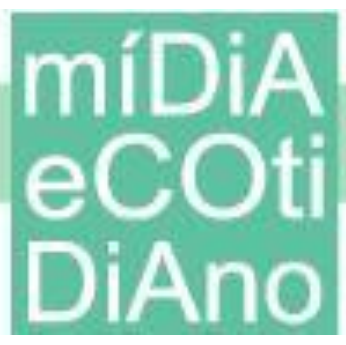

abordagens transversais. É o caso da inclusão na sua obra do positivismo de Auguste Comte, que o inspirou a refletir sobre um "poder espiritual" e um "acordo dos espíritos". É no caráter proteiforme (que assume diferentes formas) do positivismo, e não só o de um regramento social, que Maffesoli investe e pode surpreender tanto seus críticos quanto seus admiradores. A crítica, não apenas como visão desalienadora da sociedade, mas também ao atacar certos profissionais, principalmente jornalistas, analistas sociais e políticos, é recorrente nos seus livros.

Apesar de sua Sociologia Compreensiva optar, como o próprio nome designa, em "compreender" mais do que julgar, Maffesoli tem seu lado crítico, como em "A república dos bons sentimentos". No que diz respeito ao oxímoro ou à forma (2), trata-se de uma característica repetida em todos os seus livros. Para desfazer as certezas, aquelas que dão conta de apenas uma visão monocórdica das coisas, Maffesoli inclui outro elemento aparentemente paradoxal, como o próprio título de um dos seus livros explicita: razão sensível. Ora, ao juntarmos o termo sensível à razão, esta passa a não ter o mesmo sentido que teria se fosse lida de forma isolada. Os exemplos se multiplicam, e por isso o oxímoro - a conjunção de elementos opostos que se complementam - é fundamental para a compreensão da obra maffesoliana. Outro livro dele também segue a mesma linha de raciocínio, que é "No fundo das aparências".

$\mathrm{O}$ reunir em termos complementares e antagônicos nos remete ao terceiro ponto, o da sensibilidade relativista ou inclusivismo (3). Incluir, em Maffesoli, tem um caráter transdisciplinar e anárquico, epistemologicamente falando, semelhante à tese do "tudo vale" (sem restrições na maneira de pensar) em Feyerabend (1993). Se um determinado pensamento ou autor "serve", inclui-se. A rejeição, para Maffesoli, é descartada por ter como base a lógica do "dever-ser", que o autor tanto combate. Estas três categorias, portanto, estão presentes em Maffesoli e moldam um estilo que poderíamos denominar de paratático. Ou seja, um conteúdo mais sugerido ou figurado do que explicitado, mais ensaístico do que exato, e conteúdo no qual existem brechas que passam a ser preenchidas pelo leitor. Se compararmos ao cinema, poderíamos identificar a parataxe maffesoliana ao estilo não-linear da narrativa fílmica do cineasta franco-suíço Jean-Luc Godard. 


\section{míDiA \\ eCO DiAno}

\section{O pensamento libertário}

As categorias quatro e cinco, respectivamente, a de caráter estilístico e a de um pensamento libertário procuram uma abordagem "desenvolta" (2007, p. 41). Considerando metodologia como o princípio heurístico, interpretativo, "nocional" (derivado de noção, e não conceitual, que é derivado da rigidez de um conceito), optamos pela mesma linha de abordagem adotada por Michel Maffesoli em seu trabalho, a de uma Sociologia Compreensiva. É a partir do que Maffesoli entende por essa metodologia que nos situamos aqui, também em relação a Heidegger. Não retomaremos os sociólogos que deram origem a esse termo, e que são, de acordo com Maffesoli, Weber (inspirado, por sua vez, em Simmel) e Pareto. É prudente salientar que Weber (2002), ao explicar a origem do termo "compreensão", oferece um leque de alternativas, o que demonstra um tipo de raciocínio ele mesmo compreensivo e relativista.

Assim, conforme Weber, a compreensão pode ser empírica (direta do significado de um ato) ou explicativa, baseada na motivação. Em todos os casos que Weber relata, e que não se limitam àqueles dois que ele próprio julgou suficientes, o princípio da compreensão é o de uma análise interpretativa (WEBER, 2002, p.16). Continuemos com Weber antes de finalizarmos este artigo retomando Maffesoli e Heidegger. Weber admite, portanto, que "a sociologia tenta abranger também vários fenômenos irracionais, isto é, míticos, proféticos, espirituais, bem como afetivos" (2002, p. 32). Pelo viés da Sociologia Compreensiva, é possível incluirmos na análise uma forma de raciocínio similar àquilo que estamos descrevendo, e julgamos ser isso extremamente necessário para que o investigador e o "objeto" de sua investigação falem a mesma língua. Se não fosse assim, a pesquisa se transformaria apenas em uma forma vazia. $E$ isso se vê muito. Em outras palavras: para falar de Maffesoli e Heidegger de modo compreensivo, precisamos ser compreensivos com o seu modo de falar.

\section{"Dasein" e cotidiano}

Outra relação de Maffesoli com Heidegger diz respeito ao que o filósofo alemão designa como o "dasein" (o Ser-Aí). Não é o caso, aqui, de nos aprofundarmos na filosofia heideggeriana, mas de procurar em Maffesoli o que nele o inspira para se referir a Martin Heidegger. Maffesoli, em “A transfiguração do político” (1997), utiliza 


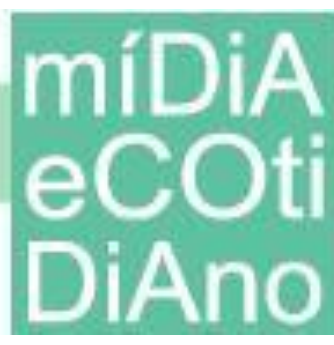

o termo "on", de Heidegger, para fazer uma analogia com a ideia de que o Eu é Outro. O “dasein”, neste caso, é sempre “on”, conforme Maffesoli: “Ou seja, o Eu não é inicialmente ele mesmo, mas o é através dos outros e segundo as modalidades do 'on'; é a partir deste que sou dado a mim mesmo" (1997, p. 207). Diferentemente de Heidegger, Maffesoli salienta, nessa mesma passagem, que o seu interesse pelo “on” não é julgá-lo, mas enfatizá-lo como um estar-junto, tema este bastante recorrente em toda a literatura maffesoliana e que, como vimos, não é o mesmo traço em Heidegger.

$\mathrm{O}$ relativismo maffesoliano, esse de matiz heideggeriana, tem o suporte, ainda, do "contraditorial": um pensamento que leva em conta as relações possíveis do que se entende por complexidade numérica. Assim, o indivíduo, transportando o tema para as formas de socialidade em Maffesoli, já não se reconhece uno, e sim plural, pelo simples (mas não tão simples assim) fato de que se vê, hoje, como "resultado" da relação com o Outro. Agora, vive não mais com o pensamento individualista no isolacionismo, mas na trágica (porque inescapável) relação a dois (pelo menos). E o par Eu-Outro traz, sempre, novas possibilidades de compreensão do real.

Maffesoli, cuja tese de doutoramento aborda a dinâmica social, que também pode ser interpretada à luz da teoria de rede de Latour, afirma que as culturas nacionais não são homogêneas, e que, em vez de pensá-las como unificadas, deveríamos pensá-las como constituindo um dispositivo discursivo que representa a diferença como unidade ou identidade. Ele argumenta que pode haver uma saturação nessa lógica clássica da identidade. O que Maffesoli põe no lugar é uma lógica da identificação, sustentada pela tese da existência de um processo e de um deslizamento progressivo de uma para a outra. A possível substituição, porém, não é o ponto do argumento maffesoliano, e sim o de que as sociabilidades contemporâneas motivam outra disposição (tanto em termos de vontade quanto de arranjo), e que isso pode ser uma das marcas da pós-modernidade ou do “dasein” heideggeriano. "O eu é apenas uma ilusão ou, antes, uma busca um pouco "iniciática"; não é nunca dado, definitivamente, mas é progressivamente, sem unidade de suas diversas expressões" (MAFFESOLI, 1996, p. 303).

O sujeito, para Maffesoli, cede lugar à pessoa. Pessoa que, conforme a raiz etimológica da palavra, se utiliza de diversas máscaras ou apresenta várias facetas que, apesar de distintas, são incorporadas por uma mesma individualidade. Uma lista de 


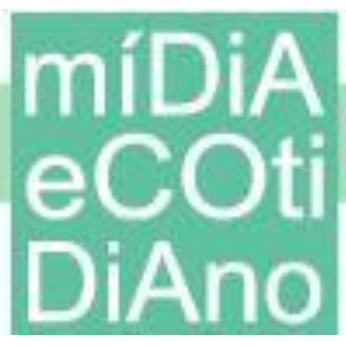

palavras pinçadas da leitura de seus livros "Sobre o nomadismo", "O tempo das tribos" e “A contemplação do mundo", entre outros, representam uma nova sensibilidade, chamada por muitos de pós-moderna. Assim, sem querer ser demasiado esquemático, teríamos na pós-modernidade expressões como: pluralidade, ambivalência, imperfeição, tremor, sedução, impermanência, holismo, dispêndio, ambiguidade e sombra. Na modernidade, prevalecem a assepsia, o indivíduo, o poder, a ordem e o progresso, o moralismo, a verdade, a autonomia, o ascetismo, a utilidade e o racionalismo.

\section{Conclusões}

A título de conclusão, vimos que mudar o modo de ser da existência pode ser a questão pós-moderna, considerando a identidade como sendo metafísica (no sentido heideggeriano de pensar sempre a questão do Ser). O Ente, por outro lado, não é o Ser, porque há nisso, segundo Heidegger, uma diferença ontológica. Maffesoli percebe o mesmo cenário ao introduzir a relação do Eu-Outro, como vimos anteriormente ao se referir ao "on" heideggeriano. Assim, tudo passa a existir na medida em que é afirmado. Essa análise da existência heideggeriana, que não é o núcleo epistêmico maffesoliano, denomina-se Analítica Existencial. Ser-aí: somos professores, mas também o somos pais, atletas, mecânicos ou cozinheiros. O Aí do Ser é uma questão de identidade, pois é ela que o define. Heidegger afirma que essa ideia é própria de um tipo de mundo - e não se refere ao pós-moderno, pois, em sua época, isso não estava em jogo conceitualmente mas não de todos. Maffesoli apresenta o tribalismo, enquanto Heidegger, filosoficamente, afirma não saber quem é o "nós".

O indivíduo em Maffesoli só é considerado na relação com o Outro, e nunca de maneira isolada. Isso nos remete à complexidade entre o todo e as partes de um determinando conjunto em Morin. Só podemos conhecer as partes se conhecermos o todo em que elas se situam. E só podemos conhecer o todo se conhecermos as partes que o compõem. O princípio do pensamento em Morin é (re)ligar, (re)unir, juntar, relacionar. A realidade, para ele, é multidimensional. Porém, tem sido estudada separadamente, e separar é "reduzir" (daí o reducionismo que Morin tanto condena). O reducionismo ignora, segundo ele, o saber sistêmico, que só existe por causa e através da ambivalência entre um dado conjunto e suas partes. O ser humano também é complexo. Cada parte de 


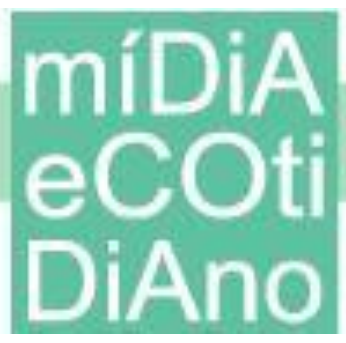

seu corpo o define. Por isso, até pode ser autônomo, mas essa autonomia é relativa. Logo, não só a parte está no todo como o todo está na parte. A parte sou eu, um indivíduo. O todo é a soma dessas partes.

Morin (2005) fez questão de organizar seu pensamento metodologicamente. Os seis livros dessa fase, que se estendeu por vários anos e que foi concluída depois da virada do milênio com a publicação de "O método 6 - Ética", apresentam como que uma unidade múltipla (unitas multiplex) da sua tese. A ideia central do último trabalho na linha das metodologias é a de que a ética não pode escapar dos problemas da complexidade, e o conhecimento complexo se tornou vital na sociedade contemporânea. É preciso praticar a complexidade, e essa prática começa no indivíduo. Maffesoli, assim, absorveu de Morin esse território complexo que é a contraditória socialidade.

O termo contradição, primeiramente, não denota um erro ou um prejuízo à coerência. Trata-se, antes, de uma função dialética. Não há oposição formal entre dois termos. Com isso, leia-se: o que há são termos ao mesmo tempo complementares e antagônicos (ideia bastante conhecida se tomarmos como argumento a obra de Morin e sua tese da complexidade). A complementaridade de termos antagônicos é semelhante na filosofia de Heidegger e, por extensão, na Sociologia Compreensiva maffesoliana, de um modo geral. Para chegarmos a um ponto final, antes, porém, teremos de nos debruçar, rapidamente, no seguinte: assim como no cinema de Godard, Maffesoli (e Heidegger) apresentam um quadro de cunho paratático. Teixeira Coelho (1995), referindo-se a Godard, salienta a parataxe como um procedimento estilístico nesse cineasta.

De acordo com Coelho, "[...] trata-se uma construção ou reconstrução poética na pós-modernidade que consiste em dispor, lado a lado, blocos de significação sem que fique explícita a relação que os une" (COELHO, 1995, p. 96). Conforme Teixeira Coelho, o que passa a existir é uma intuição da presença de um bloco em relação a outro, e não uma referência explícita. Ele acrescenta: "É como se entre o conjunto dos blocos e a significação final mediasse um vazio, um buraco negro, a ser preenchido pela justaposição" (COELHO, 1995, p. 96). Pois essa parataxe, observada por Teixeira Coelho, é um formato recorrente em Godard e Maffesoli. Em Viver a vida (1962), por exemplo, Godard divide seu filme em 12 blocos. E, daí em diante, é o espectador que dá sentido a ele. Os blocos são apenas apresentados, dispostos (como salientou Teixeira 


\section{míDiA

Coelho). A dialética, aqui, consiste nesse fator intuitivo entre o Eu e a imagem. É a mesma natureza dialética entre o Ser e o Ente, de Heidegger, ou o Eu-Outro maffesoliano.

Vattimo, intérprete de Heidegger, também se refere às polarizações do autor de "Ser e tempo". Segundo ele, analisando Heidegger, "o pensamento [de Heidegger] é definido como sendo polarizado entre a atenção ao indivíduo e as suas experiências mais profundas (a angústia, a morte) e a circunstância de pertencer ao mundo” (1998, p. 155). Godard também polariza ao relatar o sentimento que tem quando vê seus filmes antigos. Revela que percebe dois movimentos distintos: “[...] é o que se pode chamar de expressão: consiste em pôr para fora alguma coisa e, depois, ao contrário, a impressão, que consiste em pôr para dentro alguma coisa" (1989, p. 53). Essa polarização, que também se dá em Maffesoli quanto ao Eu-Outro, é uma dialética mais próxima da dialética bachelardiana do sincretismo entre polos objetivos e subjetivos. Polaridades entre a busca e o dado. Isso porque existe a boa e a má dialética, conforme Merleau-Ponty. "Só é boa dialética aquela que se critica a si mesma.

A má dialética termina no cinismo, no formalismo por evitar seu próprio duplo sentido" (MERLEAU-PONTY, 2014, p. 95). Consideramos, para análise neste artigo, Godard, Maffesoli e Heidegger uma tríade de "bons" dialéticos, portanto.

Assim o é pelo fato de que a questão dialética é um fundamento tanto para Maffesoli quanto para Heidegger e Godard. Nietzsche, outro pensador dialético, explica em “A filosofia na era trágica dos gregos" (2008), retomando Anaximandro: "Como pode perecer algo que tem direito a existir?” (2008, p. 53). Esse era o dilema de Anaximandro. Heráclito deu continuidade ao pensamento de Anaximandro e falou do vir-a-ser. Todo "vir-a-ser", de Heráclito, surge da guerra dos opostos, observa Nietzsche (2008). Dialética, portanto, são polaridades. Assim, chegamos à Filosofia Polar, que é o desmembramento de uma força em dois polos opostos (as antinomias clássicas). E assim, também, concluímos com a percepção de que, dentro de um quadro em que a dilética é palavra-chave, tanto Maffesoli quanto Heidegger, ambos fenomenólogos das ciências humanas, procuram o homem da potência. 


\section{míDiA \\ ecc DiAno}

Referências

COELHO, T. Moderno pós-moderno. Modos e versões. São Paulo: Iluminuras, 1995.

FEYERABEND, P. Contra o método. Lisboa, Relógio d’Água, 1993.

GODARD, J. Introdução a uma verdadeira história do cinema. São Paulo: Martins Fontes, 1989.

HEIDEGGER, M. Ensaios e conferências. Petrópolis, RJ: Vozes, 2008.

Os problemas fundamentais da fenomenologia. Petrópolis, RJ: Vozes, 2012. Ser e tempo. Petrópolis, RJ: Vozes, 2015.

MAFFESOLI, M. No fundo das aparências. Rio de Janeiro: Vozes, 1996. 1997.

A transfiguração do político. A tribalização do mundo. Porto Alegre: Sulina,

O conhecimento comum. Introdução à Sociologia Compreensiva. Porto Alegre: Sulina, 2007.

A república dos bons sentimentos. São Paulo: Iluminuras, 2009.

Pactos emocionais. Reflexões em torno da moral, da ética e da deontologia.

Curitiba: PUCPRESS, 2018

MERLEAU-PONTY, M. O visível e o invisível. São Paulo: Perspectiva, 2014.

MORIN, E. O método 6. Ética. Porto Alegre: Sulina, 2005.

NIETZSCHE, F. A origem da tragédia. Lisboa: Guimarães Editores, 2002.

A filosofia na era trágica dos gregos. São Paulo: Hedra, 2008.

RÜDIGER, F. Civilização e barbárie na crítica da cultura contemporânea. Leitura de Michel Maffesoli, Porto Alegre: EDIPUCRS, 2002.

VATTIMO, G. O fim da modernidade. Niilismo e hermenêutica na cultura pósmoderna. São Paulo: Martins Fontes, 1996.

Introdução a Heidegger. Lisboa: Instituto Piaget, 1998.

WEBER, M. Conceitos Básicos de Sociologia. São Paulo: Centauro, 2002. 